\title{
Çalışma Yaşamında Manganez Maruz Kalımının Sağlık Etkileri ve Parkinsonizm
}

\author{
Health Effects of Manganese Exposure at Workplace and Parkinsonism
}

\author{
Zehra GÖK METiN (D) , Abdulsamet SANDAL iD , Ali Naci YILDIZ
}

\begin{abstract}
ÖZET
Yaygın olarak kullanılan, bir ağır metal olan manganez (Mn), biyolojik fonksiyonları yürüten birçok enzimatik işlem için gerekli olan bir eser elementtir. Bununla birlikte, Mn'e aşırı maruz kalım, toksisiteye yol açmaktadır. Bu toksisitenin santral sinir sistemine etkileri özel önem taşımaktadır. Mn aşırı maruz kalımı tipik olarak parkinsonizm olarak ortaya çıkmakta ve daha yaygın görülen idiyopatik Parkinson hastalığından ayırt edilmesi zor olabilmektedir. Mesleki ve çevresel maruz kalıma ek olarak, sistemik hastalıklar, total parenteral beslenme ve bazı ilaçlar Mn toksisitesinin diğer potansiyel etiyolojileri arasında sayılabilir. Bu derlemede; Mn mesleki ve çevresel maruz kalımı, patofizyolojisi ve klinik özellikleri ele alınmıștır. Ayrıca, Mn'in iş yerindeki etkisi ve bir toksisitenin nörodejeneratif bir hastalık olarak tanılanmaması için ayrıntılı bir mesleki ve çevresel öykünün gerekliliği vurgulanmıştır. Kapsamlı bir tedavinin yokluğunda, erken tanı ve önleyici tedbirlerin zamanında başlatılması, Mn toksik etkilerinin yönetilmesinin anahtarıdır.

Anahtar Kelimeler: İș sağlığı ve güvenliği, manganez, parkinsonizm, toksikoloji.
\end{abstract}

\section{ABSTRACT}

Manganese (Mn), a heavy metal commonly used in industry, is a trace element required for many enzymatic processes that drive biological functions. However, excess exposure to Mn leads to toxicity. Its toxic effects on the central nervous system are important. The typical manifestation of Mn over exposure is parkinsonism, which may be challenging to differentiate it from more common idiopathic Parkinson's disease. In addition to occupational and environmental exposure to $\mathrm{Mn}$, other potential etiologies causing $\mathrm{Mn}$ toxicity include systemic diseases, total parenteral nutrition and some drugs. In this review, we evaluated occupational and environmental exposure of $\mathrm{Mn}$, its pathophysiology and clinical characteristics. We have highlighted the impact of Mn exposure at the workplace and emphasize the necessity of a detailed occupational and environmental history to ensure that a toxicity is not misdiagnosed as a neurodegenerative disease. In the absence of a comprehensive treatment, early diagnosis and timely initiation of preventive measures are the keys to managing Mn toxic effects.

Keywords: Manganese, Occupational Health and Safety, Parkinsonism, Toxicology.

Zehra GÖK METiN | zehragok85@hotmail.com

Hacettepe Üniversitesi, Hemşirelik Fakültesi, İç Hastalıkları Hemşireliği Anabilim Dalı, Ankara, Türkiye

Hacettepe University, Faculty of Nursing, Internal Medicine Nursing Department, Ankara, Turkey

Absulsamed SANDAL | asandal@hotmail.com.tr

Ankara Mesleki ve Çevresel Hastalıklar Hastanesi, İ̧̧ ve Meslek Hastalıkları Kliniği, Türkiye

Ankara Occupational and Environmental Diseases Hospital, Occupational Diseases Clinic, Turkey

Ali Naci YILDIZ | alinaciyildiz@gmail.com

Hacettepe Üniversitesi, Tıp Fakültesi, Halk Sağlığı Anabilim Dalı, Ankara, Türkiye

Hacettepe University, Faculty of Medicine, Public Health Deparment, Ankara, Turkey 


\section{MANGANEZ VE MINNERAL YAPISI}

Manganez (Mn), toprak, su ve kayalıklarda doğal olarak bulunan, yer kabuğunun \%0,1'ini oluşturan, baz metal halinde olmayan, gri-beyaz, sert, kırılgan bir elementtir $[1,2]$. Manganez, sülfit, oksit, karbonat, silikat vb. yüzden fazla mineral ile bileşik yapmaktadır. Manganezin organik ve inorganik olarak formları $+2,+3,+4$ ve +7 değerlikli olup $\mathrm{MnCl}_{2}, \mathrm{KMnO}_{4}, \mathrm{MnSO}_{4}, \mathrm{MnPO}_{4}, \mathrm{MnO}_{2}, \mathrm{Mn}_{3} \mathrm{O}_{4}$ şeklinde gösterilmektedir [3]. Okyanus olayları, depremler, volkanik patlamalar, yangınlar ve bitki örtüsü değişikliği gibi durumlar yer kabuğu hareketlerinin artmasına ve atmosfere Mn salınmasına yol açmaktadır [3-5]. Allotroplarıyla birlikte $7,21-7,44 \mathrm{~kg} / \mathrm{dm}^{3}$ arasında özgül ağırlığı olan saf Mn'in ergime noktası $1244^{\circ} \mathrm{C}$, kaynama noktası 2060 ${ }^{\circ} C^{\prime}$ dir. Saf formu demire benzeyen Mn demirden daha sert ve kırılgan bir metaldir. Periyodik cetvelin 7B grubunda yer alan Mn'in atom numarası 25, atom ağırlığı yaklaşık 55 g/mol'dür[3]. Manganez elementi Şekil 1'de gösterilmektedir.

Şekil 1: Manganez elementi

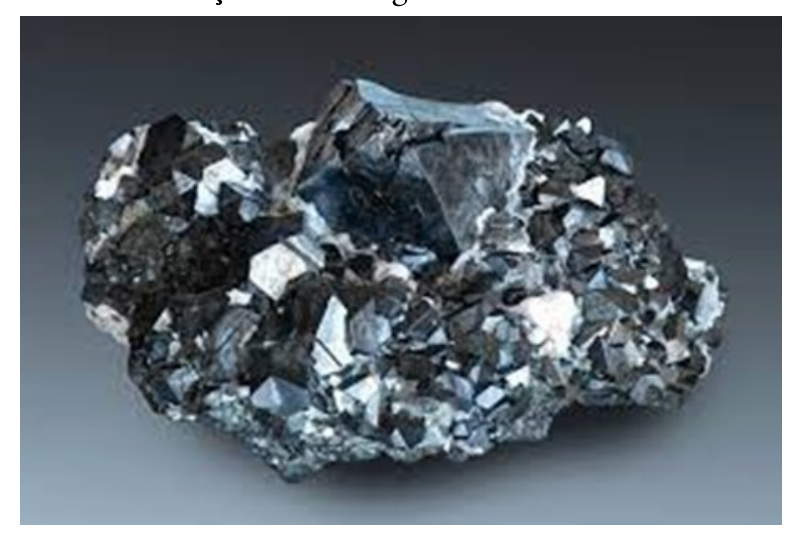

\section{MANGANEZIN KULLANIM ALANLARI, MESLEKİ VE ÇEVRESEL MARUZ KALIM}

Günümüzde Güney Afrika, ardından Avustralya, Çin, Gabon ve Brezilya dünyanın en büyük Mn üretici ülkeleri arasındadır [6]. Demir-çelik endüstrisinde farklı çelik türlerinin içeriği için gerekli olan Mn cevherinin 2017 yılında küresel üretimi 20 milyon ton olarak bildirilmiştir. Manganez ve bileşikleri endüstride sertlik sağlamak ve dayanıklılığı arttırmak amacıyla çelik, pil, kibrit, havai fişek üretiminde, cam ve seramik sanayisinde, hayvan yemleri, gübre ve pestisit üretiminde kullanılmaktadır [7]. Manganez özellikle metal endüstrisinde demiri sertleştirmede, demir ile birlikte alüminyum, antimon ve bakır alaşımını oluşturmada kullanılabilmektedir. Pil (manganez klorid ve dioksit), gübre (manganez sülfat), yakıt karışımı (MMT), antiseptik (potasyum permanganat), yem katkı maddesi (manganez sülfat ve karbonat), günlük diyet desteği (manganez klorid), cam endüstrisi (manganez sülfat), pestisitler (maneb) ve medikal görüntüleme Mn’in ağırlıklı kullandığı alanlardir [8].

Doğada volkanik aktiviteler sonucu, kontamine su ve havada, taşlarda bulunan Mn'e mesleki maruz kalım genellikle toz ve buharların solunması sonucu meydana gelmektedir. Kaynakçılar, madenciler, arıtma çalışanları, demirçelik üreticileri, pil üretim çalışanları, enerji santrali, kok fırın ve garaj çalışanları ve taksi şoförleri riskli meslek gruplarını oluşturmaktadır [9].

Manganez mesleki maruz kalımı açısından kaynak sektörü ayrı bir öneme sahiptir. Kaynakçılıkta $4000{ }^{\circ} C^{\prime}$ nin üzerindeki sıcaklıklarda baz metaller ve kullanılan elektrotlar birleştirilmek üzere isıtılmaktadır. Bu sırada çoğunluğu kullanılan elektrottan kaynaklanan, buharlaşan bir duman ortama salınmaktadır. Buharlaşan metaller hava ile reaksiyona girerek solunabilir büyüklükte metal oksit partikülleri oluşturmaktadır [10-12]. Dünyaya her yıl kaynak endüstrisinden 5000 ton kaynak dumanı salındığı tahmin edilmektedir [13]. Oluşan dumanın fiziksel ve kimyasal özellikleri kullanılan metal ve kaynak yöntemine göre değişmektedir [14]. 
Dünyada yapılan araştırmalar, madencilik endüstrisinde ve eritme veya kaynak mesleklerinde çalışanlarda $\mathrm{Mn}$ maruz kalımının nörolojik yan etkilerini ele almıştır. İsveç, Belçika, Singapur, Güney Afrika ve İtalya'da Mn'e maruz kalan çalışanlarda nörobilişsel kusurlar bildirilmiştir. Sözü edilen araştırmalarda, kronik Mn intoksikasyonuna maruz kalan çalışanlarda nörobilişsel testlerde bozukluk ve sözel akıcılığın zayıflaması, reaksiyon süresinin uzaması, motor hızın azalması, görsel-motor işleme, el-göz koordinasyonu ve el sabitliğinin korunamaması gibi nörolojik disfonksiyonlar geliştiği raporlanmıştır [15-17]. Pennsylvania'da yapılan bir kaynakçı kohortunda, düşük seviyelerde kronik Mn maruz kalımında dahi, hareket bozuklukları ile sonuçlanan bazal ganglionlarda değişiklikler geliştiği bildirilmiştir [18].

Kaynak ve madencilik sektörlerinin dışında, bazı ülkelerde Mn'e çevresel maruz kalım da söz konusu olmaktadır. Dünya Sağlık Örgütü (WHO)'ne göre, içme suyunda izin verilen maksimum $\mathrm{Mn}$ konsantrasyonu $400 \mu \mathrm{g} / \mathrm{L}$ 'dir. Bangladeş, İtalya ve Kanada'da, bu değerin üzerinde $\mathrm{Mn}$ konsantrasyonuna bağlı olarak kirlenmiş içme suyundan dolayı toksik etkiler rapor edilmiştir [19]. Ayrıca, Kanada, ABD, Fransa, Arjantin ve Avustralya'da yüksek trafik yoguunluğuna bağlı olarak metil siklo penta dienil manganez trikarbonil (MMT) toksik etkilenimi ve kronik olarak ditiyokarbamat fungisitlere maruz kalma nedeniyle Mn toksikasyonları bildirilmiştir [20,21]. Kanada Quebec'te eski bir Mn alaşım üretim tesisinin yakınında yaşayan yaşı bireylerde yapılan çalışmada, kan Mn seviyeleri ile psikomotor yavaşlama arasında ters bir ilişki olduğu ve Mn maruz kalımının işitsel hatırlama ve görsel tanıma testleri, duygudurum semptomları ve performans üzerinde doğrudan etki gösterdiği raporlanmıştır. Bu çalışma, özellikle çevredeki yüksek $\mathrm{Mn}$ seviyelerine mesleki olmayan maruz kalımın sağlığa etkilerini değerlendiren ilk çalışma olması açısından dikkat çekicidir [22]. Benzer şekilde, Mn ferroalyaj tesislerinin çevresinde yaşayan bireylerde de Mn'e maruz kalımın uzun sürede Parkinsonizm ve postüral bozukluk riskini arttırabileceği ortaya çıkarılmışırı $[23,24]$. Bunlara ek olarak, çocuklar emilimin daha yüksek olması ve vücut kütlelerinin düşük olması nedeniyle $\mathrm{Mn}$ toksisitesi açısından daha yüksek risk alındadır [25]. Çocuklarda Mn maruz kalımının gelişimsel gerilik ve zekâ geriliğine (düşük IQ puanları) yol açtığı bildirmiştir [26].

Çevresel etkilenime ek olarak, tıbbi uygulamalar sırasında da Mn toksisitesi gelişebilmektedir. Normal şartlarda, total parenteral nütrisyon (TPN) solüsyonları ek destek olmaksızın 7,3 $\mu \mathrm{g} / \mathrm{L}$ Mn içermektedir. TPN solüsyonlarına bu değerden fazla Mn eklenmesi bağırsaklardan Mn emiliminin artmasına ve beyinde toksik birikime yol açabilmektedir [27]. Abdalian ve ark. [28], Amerikan Parenteral ve Enteral Beslenme Derneği-ASPEN'in ortalama günlük (150-800 $\mu \mathrm{g} / \mathrm{gün}) \mathrm{Mn}$ takviyesi ile TPN solüsyonu kullanan 16 hastanın Mn düzeylerini değerlendirdiği araştırmada yüksek kan Mn'in manyetik rezonans beyin görüntülemesinde pallidum sinyalinde değişikliklerle ilişkili olduğu bulunmuştur. Bu araşıırma sonuçlarına dayanarak, nörolojik etkilenim riskini azaltmak için ASPEN kılavuzlarını güncellemiş ve önerilen $\mathrm{Mn}$ düzeylerinin 60-100 $\mu \mathrm{g} / \mathrm{g}$ 'ye düşürülmesini önermiştir.

Ayrıca, ülkemizde Rus kokteyli (efedrin, asetilsalisilik asit ve potasyum permanganat içeren psikostimülan) olarak adlandırılan ilaç karışımının intravenöz kullanımına bağlı olarak yedi hastada Mn toksisitesi ilişkili parkinsonizm bildirilmiştir [29].

\section{MANGANEZIN FONKSIYONLARI}

Manganez organizmada proteinlere bağlı olarak bulunan esansiyel bir elementtir. Fosforilasyon, kolesterol ve yağ asitleri sentezinde rol oynayan bazı enzimatik reaksi- 
yonlar için kofaktör rolü bulunmaktadır [9]. İnsan vücudu için esansiyel olan Mn'in erişkin bireylerde ortalama günlük gereksinim 2-5 mg olarak değişmektedir [30]. Erişkin bireylerde $M n^{\prime}$ in kandaki düzeyi $9 \mu \mathrm{g} / \mathrm{L}$ 'dir $(4-15 \mu \mathrm{g} / \mathrm{L})$ [31,32]. İçme suyunda genel olarak $100 \mu \mathrm{g} \mathrm{Mn} / \mathrm{L}$ ve altına izin verilmektedir. Manganez, insan vücudunda enerji metabolizması, sinir sistemi hücrelerinin gelişimi ve fonksiyonları ve antioksidan savunma sisteminde önemli roller almaktadır. Manganez aminoasit, kolesterol ve karbohidrat metabolizması ve kemik formasyonuna katılmakta, serbest oksijen radikallerine bağlı hasardan hücreleri korumaktadır. Piruvat karboksilaz ve süperoksit dizmutaz enzimlerinin yapısına katılmaktadır [33].

\section{MANGANEZ MARUZ KALIMI VE SAĞLIK ETKILERI}

Manganez vücuda solunum yolu ve oral yoldan, nadiren olfaktör sinir (burunda, koku siniri) yolu ile de alınmaktadır. Organik Mn bileşikleri cilt bariyerini geçebilirken inorganik bileşikleri geçememektedir. Mukosiliyer aktiviteyle uzaklaştırılan Mn partiküllerinin bir kısmı yutularak gastrointestinal sisteme ulaşabilmektedir [34]. Solunum yolu ile maruz kalımda $\mathrm{Mn}$, partikül büyüklüğü ve sudaki çözünürlüğüne bağlı olarak alveolar-kapilar membrandan \%40-70 oranında emilmektedir. Manganez diyetle başlıca tahıllar, meyveler, sebzeler, çay ile alınmakta ve yutulduğunda ince bağırsaktan yaklaşık \%3-4 oranında emilim göstermektedir. Gastrointestinal absorbsiyonu oldukça düşük olan Mn, demir metabolizmasından etkilenmektedir [35]. Absorbe edilen Mn plazmada beta-1globulin ve transferrine bağlı olarak taşınarak tüm vücuda dağılmaktadır. Mitokondriden zengin organlarda birikim göstermekte, kan-beyin bariyerini ve plasentayı geçebilmekte; retina, koyu saç ve cilt gibi pigmentten zengin dokularda birikim göstermektedir [36]. Başlıca karaciğer, pankreas ve böbreklerde ve daha az oranda kemik ve yağ dokusunda birikmektedir. Yarılanma ömrü 30 saattir. Ana atılımı, giriş yolundan bağımsız safra salgısı ve dışkı ile gerçekleşmektedir. İdrar ile sadece \%6'lık kısmı atılabilmektedir. Bu oran; yaş, cinsiyet, sigara ve alkol kullanımına bağlı olarak değişkenlik göstermektedir [37].

Manganez, vücuda yüksek dozda alındığında akut etkilere ve kronik maruz kalımda bazı sağlık sorunlarına yol açmaktadır [38,39]. Doğal olarak kayalarda, toprakta ve suda bulunmasına rağmen genelde insanlarda Mn maruz kalımı besin yolu ile olmaktadır [40]. Toprak kaymaları, yer kabuğunun hareketleri gibi doğal olaylar, bitkilerdeki Mn birikim miktarını artırarak besin çevrimi yoluyla insan maruz kalım miktarını artırmaktadır. Dünya Sağlık Örgütü, Mn maruz kalımının en temel kaynağının bitkisel kaynaklı, pirinç buğday ve çay olduğunu raporlamıştır. Ayrıca, bir Mn türevi olan MMT 1950'li ylllardan bu yana motorlu araçlarda vuruntu önleme performansını ve oktanı arttırmak için yakıt bileşeni olarak kullanılmaktadır. Kurşunsuz benzin, gaz, dizel yakıtta yanmayı arttırıcı olarak tercih edilmektedir. MMT yaklaşık \%24 Mn içermekte ve kurşunsuz benzinde 5-20 ppm Mn konsantrasyonu kullanılmaktadır [41]. Amerika Birleşik Devletleri Çevre Koruma Ajansı (EPA) oktan arttırıcı yakıt katkısı olarak MMT kullanımının Mn maruz kalımı açısından potansiyel bir halk sağlığı sorunu olduğunu bildirmektedir [30, 41].

\section{A. Manganez Akut Etkilenimi ve Klinik Bulgular}

Manganezin oral alımına bağlı nadir olarak zehirlenme durumu gelişmektedir [42]. Mesleki ortamlarda solunum yolu ile akut maruz kalım sonucu öncelikle Mn pnömonisi gelişmektedir. Yüksek dozda Mn tozu bulunan bitkilerle çalışan erkeklerde, epitelyal nekroz ve bunu takiben mononükleer proliferasyon gibi patolojik değişikliklerin ortaya çıktığı ve solunum yolu hastalık sıklığının normalden 30 kat daha fazla olduğu bildirilmiştir. İnorganik Mn'in akut 
toksik etkileri çok az görülmektedir. Ciltte ve mukozalarda irritasyon, yüksek doz maruz kalımda hava yolu irritasyonu, bronşit, pnömoni ve solunum fonksiyon testlerinde bozulma gibi bulgulara neden olmaktadır [9]. Mn ve Manganez dioksit $\left(\mathrm{MnO}_{2}\right)$ dumanı inhalasyonuna bağlı titreme, öksürük, ateş, karın ağrısı, vücut ve baş ağrısı, kusma ve halsizlik gibi semptomların görüldüğü "metal dumanı ateşi” gelişebilmektedir. Bu semptomlar, Mn buhar maruz kalımından birkaç saat sonra başlayıp 24 saatte sonlanmaktadır, ancak bu durum Mn’e özgü değildir ve diğer metal oksit maruz kalımlarında (örn. çinko oksit) da görülebilmektedir [43]. Organik Mn bileşiği olan MMT deri ve göz irritasyonu, kontakt dermatit, bulantı, baş ağrısı, baş dönmesi gibi sorunlara neden olabilmekte, nadiren böbrek ve karaciğer hasarı da gelişebilmektedir [9].

\section{B. Manganez Kronik Etkilenimi, Manganizm ve Par-}

\section{kinson Hastalığ}

Uzun süreli $\mathrm{MnO}_{2}$ 'e inhalasyon yoluyla maruz kalım sonucunda merkezi sinir sistemi hasarı oluşabilmektedir. Manganez vücuda alındıktan sonra uzun dönemde beyinde özellikle bazal gangliyonlarda birikmekte, sinir sistemi hasarına yol açmakta ve Parkinson hastalığına benzer bulgulara neden olmaktadır. Sinir sistemi etkilenimi gelişen çalışanlarda öncelikle yürüyüş ve el koordinasyonu bozulmaktadır (38). Manganez inhalasyon yoluyla aşırı düzeyde alındığında yüz kaslarında spazm, yürüme zorluğu ve titreme gibi semptomların geliştiği kalıcı nörolojik hastalıklara da yol açabilmektedir [44]. Kronik Mn etkilenimine bağlı olarak gelişen zehirlenme (manganizm) tablosunda yukarıda sayılan semptomların yanı sıra irritabilite, konuşma bozukluğu, kompulsif davranışlar gibi nöropsikiyatrik rahatsızlıklar da gelişebilmektedir. Manganez zehirlenmesi devam ederse, maske yüz, Parkinson benzeri bir sendrom gelişebilmekte, Mn ensefalopatisi ve siroz ortaya çıkabil- mektedir. Kronik Mn zehirlenmesinde maruz kalım kesildikten sonra iyileşme yavaş seyredebilmektedir [35, 36]. Ülkemizde yürürlükte olan mevzuatta ortamda Mn düzeyine ilişkin sınır değerleri içeren bir hüküm bulunmamakla birlikte, Amerika Birleşik Devletleri İş Sağlığı ve Güvenliği İdaresi (OSHA), Mn bileşikleri ve dumanı için maruz kalım sınırını (PEL) $5 \mathrm{mg} / \mathrm{m}^{3}$ zaman ağırlıklı ortalama (TWA) olarak bildirmiştir [37].

\section{Manganizm}

Manganez maruz kalımına bağlı nörotoksisite, bazal ganglionlar, globuspallidus, substantianigra pars retikulata ve özellikle savunmasız yapılar olarak tanımlanan striatumda nöronal kayba neden olmaktadır [45]. Striatumda yüksek seviyelerde Dimetiltriptamin (DMT1) eksprese edilmekte, pallidum ve substantia nigra $\mathrm{Mn}$ birikim bölgeleri ile uyumluluk göstermektedir [46]. Manganez maruz kalımı nedeniyle beyinde dopamin açısından zengin bölgelerin ve pallidumun spesifik tutulumu, Mn'i bağlayan ve onu dopamin bakımından zengin bölgelerde biriktiren dopamin taşıyıcısına (DAT) atfedilmektedir. Bazal gangliyonlara ek olarak, Mn toksisitesinde beyincik, kırmızı çekirdek, pons ve omuriliğin ön boynuz hücreleri de etkilenebilmektedir $[19,47]$.

Manganez toksisitesine bağlı olarak hücre düzeyinde mitokondriyal disfonksiyon, proteinlerin yanlış dizilimi ve nöroinflamasyondan oluşan "nörotoksik üçlü" birlikte görülmektedir [49]. Manganez, kalsiyum birikimine yol açan kalsiyum akışını inhibe ettiği için mitokondriyal matrikste birikmektedir. Yüksek matriks kalsiyum seviyeleri, reaktif oksijen türlerinin oluşumunu artırarak Mn'in toksik etkilerine aracılık etmektedir [49,50]. Güney Afrika Mn maden işçilerine ait otopsi çalışmasında, globus pallidusta daha yüksek mikroglial yoğunluk ve kaudatta daha düşük astrosit yoğunluğu olduğu gösterilmiştir. Mn ile ilişkili 
nörodejenerasyon başlangıçta bazal gangliyonlarda mikroglial infiltrasyona ve takiben nöronal kayıpla birlikte astrosit hasarına yol açabilmektedir [51]. Manganez, esas olarak astrositlerde eksprese edilmekte ve glutamatı glutamine dönüştüren glutamin sentetaz (GS) enzimi için bir kofaktör görevi üstlenmektedir. Manganeze kronik maruz kalan bireylerde GS enzim aktivitesi azalmakta, böylece glutamaterjik sinyalleme artmaktadır. Ek olarak, kronik Mn intoksikasyonu, astrositler yoluyla sinaptik glutamat temizlenmesinden esas olarak sorumlu olan glutamat aspartat taşıylcısının seviyelerini azaltmaktadır. Bu iki mekanizmanın, manganizmde glutamaterjik eksitotoksisitenin ve bunu izleyen nöronal kaybın altında yatan nedenler olduğu öne sürülmektedir [52].

Manganeze maruz kalım zamanla bilişsel, davranışsal ve ekstrapiramidal işlev bozukluğu ile karakterize Mn nörotoksisitesinin karmaşık sendromu olan "manganizme" yol açmaktadır. Erken evrede psikiyatrik semptomlar daha sık görülürken, zamanla minimal düzeyde titreme, eksenel ve apendiküler distoni ve 'horoz yürüyüşü' olan bir akinetik sendrom ortaya çıkmaktadır [53]. Manganez maruz kalımı ekstrapiramidal disfonksiyona neden olmakla birlikte, $\mathrm{Mn}$ toksisitesinin klinik özellikleri idiyopatik Parkinson hastalığında görülenlerden oldukça farklıdır. Parkinson hastalığı, ilerleyen yaşta daha sık görülürken, Mn ilişkili parkinsonizm, çeşitli iş kollarına mensup çalışma çağındaki kişileri etkilemektedir [54]. Manganizm, psikiyatrik semptomlarla (Mn delilik veya lokura manganik) yavaş yavaş başlayıp, ardından davranısssal ve psikiyatrik anormalliklere yol açmaktadır. Semptomların simetrik başlaması, istirahat tremorundan daha çok hareket sırasında titreme görülmesi ve dopamin tedavisine yanıtın düşük olması manganizm ile Parkinson hastalığı arasındaki en temel farklardır $[55,56]$. Manganizmde gelişen 'horoz yürüyüşünde', genel distonik duruş nedeniyle dik bir omurga ve dirseklerde fleksiyon ile topuklar yere değmeden ayak parmakları üzerinde durma karakteristik bulgudur. Bu hızlı adım yürüyüşü, tavuğun hızlı koşması sırasında oluşan görüntüye benzemektedir. Dolayısı ile bu yürüyüş özelliği ile Parkinsonvari yürüyüş birbirinden ayırt edilmelidir. Andruska ve ark.'nın [55], Mn'e maruz kalan 4000'den fazla çalışanı inceledikleri araştırmada çalışanlarda bu karakteristik yürüyüşün gözlenmediği bildirilmiştir. Yazarlar, maruz kalım süresi ve miktarının, hafif titreme ve bradikineziden şiddetli hipokinezi ve kendine özgü yürüyüş disfonksiyonuna kadar geniş bir yelpazede semptomlara yol açtı̆̆ını ifade etmişlerdir [55]. Aynı çalışmada, Mn maruz kalımının kesilmesinden on yıl sonra, hastaların benzer semptomları deneyimlemeye devam ettikleri raporlanmışır [55]. Ayrıca, yapılan beyin görüntülemede sinyal değişiklikleri olmamasına rağmen Parkinson semptomlarının ilerlemesinin dikkat çekici olduğu vurgulanmıştır. Manganez, globus pallidus ve substantia nigra çekirdeklerini uzun vadeli olarak etkilemekte, ilerleyici hasara neden olmaktadır [57]. Araştırmalar incelendiğinde; manganizme bağlı Parkinson benzeri semptomlar gelişen hastalarda, Parkinsona kıyasla tremorun atipik olduğu, distoninin daha sık görüldüğü (yüz buruşturma, horoz yürüyüşü), başlangıç aşamasında geriye doğru düşmenin daha sık geliştiği ve levodopaya yanıtın zayıf olduğu veya sürekli yanıt alınamadığı bildirilmiştir $[58,59]$. Ghosh ve ark. [60], yüksek Mn konsantrasyonlu çay tüketimi sonrası bilişsel işlev bozukluğu ve koreiform hareketler ile başvuran bir çay satııısında yakın zamanda Mn toksisitesi geliştiğini belirtmişlerdir. Başka bir araştırmada da aşırı düzeyde kronik Mn maruz kalımı nedeniyle parkinsonizm olmaksızın miyoklonik kasılmalar gelişebileceği vurgulanmıştır [61]. Bu nedenle, araştırmalar ve vaka sunumları dikkate alındığında $\mathrm{Mn}$ toksisitesi olan bireylerde hareket bozukluklarının farklılıklar gösterebileceği, ayrıntılı mesleki ve çevresel öykü alınmasının gerekli olduğu akılda bu- 
lundurulmalıdır.

Manganez, sinir sistemine olan yıkıcı etkilerinin yanı sıra, üreme fonksiyonlarında da azalmaya neden olmaktadır. Manganez kan-beyin bariyerini aşarak, gebelerde düşük dozlardaki maruz kalımlarda dahi plasentadan geçerek fetüs için zararlı etkiler gösterebilmektedir. Mn maruz kalımına bağlı çocuklarda yetenek, öğrenme ve hafıza odaklı boyutlarda beyin gelişiminin olumsuz etkilendiği ve geçici ya da kalıcı yürüme ve konuşma bozuklukları oluştuğu bildirilmektedir $[25,26]$. Liu ve ark.'nın plasenta Mn düzeyi ile nöral tüp defekti (NTD) riski arasındaki ilişkiyi inceledikleri bir vaka kontrol çalışmasında NTD'li 80 fetüs veya yenidoğan ve 50 sağlıklı yenidoğan plasentasında $\mathrm{Mn}$ düzeyini ölçmüşlerdir. NTD’li grupta plasenta $\mathrm{Mn}$ ortanca konsantrasyonunun kontrol grubundan anlamlı düzeyde yüksek olduğu, ortanca değer üzerinde Mn konsantrasyonuna sahip olanlarda NTD riskinin 4 kat fazla olduğu gösterilmiştir [62]. Bu etkilerin, eve götürülen maruz kalımlar (İng. take-home exposure) açısından da önem taşıyabileceği akılda tutulmalıdır.

\section{LABORATUVAR VE GÖRÜNTÜLEME BULGULARI}

Kan ve idrar dışında, saç ve tırnak gibi noninvazif biyolojik materyaller mesleki ve çevresel toksinlere uzun süreli maruz kalımı değerlendirmede kullanılmaktadır [63]. Güvenilir sonuçlar vermemekle birlikte saç mineral analizi toksik elementlere maruz kalımın biyolojik izleniminde tercih edilebilmektedir [65]. Günümüzde Mn maruz kalımını gösteren spesifik bir biyomarker bulunmamasına rağmen, kan ve idrar Mn düzeyi akut maruz kalımı işaret edebilmekte, kronik maruz kalım açısından kesin bilgi vermemektedir. İş yerlerinde maruz kalımı değerlendirmek açısından kan ve idrarda Mn düzeyinin bakılması yararlı olabilmektedir [65, 66]. Ayrıca lökosit ve hemoglobin seviye- lerinde hafif düşüklük, nadiren karaciğer enzim düzeylerinde yükseklik görülebilir [2]. Parkinson hastalı̆̆ında olduğu gibi Mn maruz kalımı ile dopamin düzeyi arasında bir ilişki gösterilememiştir [9].

Manganezin paramanyetik özelliklerinden dolayı, pallidumda birikmesi, manyetik rezonans görüntülemede (MRI) globus pallidusta hiperintensiteler olarak tespit edilmekte ve beyinde karakteristik bir MRI bulgusu olarak değerlendirilebilmektedir [28]. Pallidal indeks (PI), globus pallidusun frontal beyaz maddeye sinyali, manganizmin asemptomatik aşamasında bile $\mathrm{Mn}$ maruziyetinin güvenilir bir belirtecidir [19]. Hiperintensiteler simetriktir ve özellikle bireylerde komşu putamen ve mezensefalona kadar uzanabilmektedir. Manganez maruz kalımında MRI'da T1 sekanslarda globus pallidusta hiperintens sinyal artışı ve zamanla sinyal artışının yayılmasına bağlı şeklinde arada posterior putamen ve kaudat nükleus da etkilenebilmektedir [68]. Pozitron emisyon tomografisi (PET), nöronal aromatik L-amino asit dekarboksilaz aktivitesini yansıtan başka bir invazif olmayan fonksiyonel görüntüleme yöntemi olup dopaminerjik presinaptik sinir terminal fonksiyonunun durumunu incelemede kullanılabilmektedir. Elektroensefalografi (EEG)'de düşük amplitüd, zayıf ritimler; nöropsikiyatrik testlerde ise unutkanlık, reaksiyon zamanında uzama, motor koordinasyonun bozulması gibi değişiklikler görülebilmektedir [3]. Bütün bu bilgiler sşığında, Mn etkilenmesinin klinik yaklaşımında toksikoloji, iş ve meslek hastalıkları, çevre sağlığı, iş sağlığı ve nöroloji uzmanlık alanlarının multidisipliner yaklaşımının önemli olduğu görülmektedir.

\section{MANGANEZ ETKILLENIMINE YÖNELIK GÜNCEL ARAŞTIRMALAR}

Özdek ve ark.'nın (2017) ülkemizde petrol istasyonu çalışanlarının saç örneklerinde $\mathrm{Mn}$ düzeyininin 
$(0.00966 \pm 0.00123)$, petrol istasyonunda çalışmayan grup$\tan (0.00397 \pm 0.0022)$ anlamlı düzeyde yüksek olduğu bulunmuştur ( $\mathrm{p}=0.019)$. Çalışmada, petrolde kullanılan MMT’nin maruz kalınan Mn düzeyini arttırabileceği, bu nedenle işçilerin $\mathrm{Mn}$ düzeyinin düzenli olarak izlenmesi gerektiği vurgulanmıştır [68].

Almanya'da yaşayan, 1989-2015 yılları arasında kaynakçılık yapan ve diğer mesleklerde çalışan bireylerin ( $\mathrm{n}=5771$ ) kişisel solunabilir Mn ölçümlerinin analiz edildiği bir çalışmada, medyan Mn konsantrasyonu kaynakçılarda $74 \mu \mathrm{g} \mathrm{m}^{3}$ ve diğer mesleklerde $8 \mu \mathrm{g} \mathrm{m}^{3}$ olarak belirlenmiştir. Medyan Mn konsantrasyonunun (>100 mg m³) gaz metal ve özlü ark kaynakçılarında ve yüksek Mn içerikli (>\%5) sarf malzemeleri kullanan korumalı metal ark kaynakçılarında yüksek olduğu raporlanmıştır. Araştırma sonunda, bildirilen sınır değerleri (OEL) elde etmek için yüksek emisyonlu kaynak tekniklerinde koruyucu önlemlerin gerektiği ifade edilmiştir [69].

Yang ve ark.'nın (2019) mesleki Mn maruz kalımının üreme hormonları ve semen kalitesi ile ilişkisini kesitsel olarak inceledikleri başka bir çalı̧̧mada, mesleki olarak Mn’e maruz kalan 84 erkek çalışan ile 92 kişiden oluşan referans grubunda idrar $\mathrm{Mn}$, semen kalitesi ve üreme hormonları ölçülmüştür. Manganeze maruz kalan işçilerde idrar Mn seviyelerinin 0,56 ile 34,25 $\mu \mathrm{g} / \mathrm{L}$ arasında değişti$\breve{g}$ i ve ortalama seviyenin $15,92 \pm 8,49 \mu \mathrm{g} / \mathrm{L}$ olduğu belirlenmiştir. Kontrol grubu ile karşılaştırıldığında, Mn'e maruz kalan grupta gonadotropin salgilayan hormon $(\mathrm{GnRH})$ düzeyleri ve lüteinizan hormon (LH) düzeylerinin önemli ölçüde yüksek ve testosteron (TSTO) düzeylerinin önemli ölçüde düşük olduğu bulunmuştur. Üriner Mn ile GnRH ve $\mathrm{LH}$ arasında anlamlı pozitif doğrusal ilişki, üriner $\mathrm{Mn}$ ve TSTO arasında doğrusal negatif ilişki olduğu rapor edilmiştir. Sperm progresif motilite ve toplam motilite, Mn'e maruz kalan grupta anlamlı düzeyde az bulunmuştur. İdrar
Mn düzeyi ile sperm progresif motilite ve toplam motilite arasında anlamlı negatif doğrusal bir ilişki olduğu ifade edilmiştir. Çalışmada, mesleki Mn maruz kalımının erkek çalışanlarda hormon salgılanmasında anormalliğe ve sperm hareketliliğinde azalmaya neden olduğu ve erkek çalışanların üreme sağlığıyla ters ilişkili olduğu sonucuna ulaşılmış$\operatorname{tir}[70]$.

Palzes ve ark. (2019) etilen fungisitlerinin püskürtüldüğü bir tarım bölgesi olan Kosta Rika'nın Zarcero ilçesindeki 48 çiftlik işçisinden oluşan bir örneklemde fonksiyonel beyin görüntüleme çalışması yürütmüşlerdir. Çiftlik işçilerinin ayak tırnaklarındaki $(\mathrm{n}=40)$ ve saçındaki $(\mathrm{n}=33) \mathrm{Mn}$ konsantrasyonları ölçülmüş ve işlevsel yakın kızılötesi spektroskopi kullanılarak dorsolateral prefrontal kortekste beyin aktivitesi kaydedilmiştir. Ayak tırnağı ve saç $\mathrm{Mn}$ konsantrasyonları sirasıly $0,40 \mu \mathrm{g} / \mathrm{g}(3,52)$ ve $0,24 \mu \mathrm{g} / \mathrm{g}$ $(3,54)$ hesaplanmıştır. Bu çiftlik işçileri örneğinde, $\mathrm{Mn}$ konsantrasyonlarının çalışan bellek ile ilgili beyin aktivitesi ile ilişkili olduğuna dair güçlü kanıt bulunamamıştır [71].

Çin'de Chen ve ark.'nın (2020) Mn'e mesleki olarak maruz kalan işçilerde kronik Mn maruziyeti ile immünolojik parametreler arasındaki ilişkiyi araştırdıkları çalışmada, 2017 yılında Mn'e maruz kalan sağlıklı işçilerin kohortunun takibi için toplam 538 işçi seçilmiştir. İşçiler; düşük maruz kalma grubu (TWA-0,15 mg/m3) ve yüksek maruz kalma (>TWA-0,15 mg/m3) grubu olarak ayrılmıştır. Bu işçilerin serum immünolojik parametreleri, lökosit sayıları ve oranları immünotürbidimetrik yöntemle incelenmiştir. Erkek çalışanlarda, yüksek maruz kalma grubunda C3

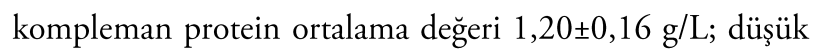
maruz kalma grubuna kıyasla önemli ölçüde daha düşük bulunmuştur $(1,25 \pm 0,18 \mathrm{~g} / \mathrm{L}, \mathrm{p}=0,023)$. Çalışmada $\mathrm{Mn}$ dumanına inhalasyon yoluyla maruz kalan erkek çalışanlarda C3 kompleman protein seviyesinin düşük olduğu, kadınlarda düşük olmadığı, fare modelleriyle bu sonuçların 
doğrulanması için ileri araştırmalara gereksinim olduğu bildirilmiştir [72].

Dlamini ve ark.'nın (2020) Güney Afrika maden işçilerinde Mn maruz kalımı, parkinson belirtileri ve yaşam kalitesi arasındaki ilişkiyi inceledikleri araştırmada katılımcıların ortalama yaşının 41,8 yıl (21-67 yaş), \%97,3'ünün erkek, inceleme sırasında tahmini ortalama kümülatif $\mathrm{Mn}$ maruz kalımının 5,4 mg Mn/m³-yll ve madende ortalama çalışma süresinin 14 yıl olduğu bildirilmiştir. Manganez maden işçileri kohortunda, parkinson belirtilerinin yaygın olduğu ve tahmini kümülatif Mn maruz kalımı ile yaşam kalitesi arasında ters ilişki olduğu ortaya çıkarılmıştır [73].

Irizar ve ark. (2021) doğum öncesi Mn maruz kalımı ile 4-5 yaşlarındaki çocuklarda nörogelişim arasındaki ilişkiyi incelemişlerdir. Araştırmada 1465 hamile kadında Mn serum konsantrasyonu ölçülmüş̧ür. Nörogelişim, McCarthy Çocuk Yetenekleri Ölçekleri ile değerlendirilmiştir. Serumdaki Mn seviyeleri ile McCarthy skalalarının hiçbiri arasında ilişki bulunamamıştır. Bununla birlikte, cinsiyete göre yapılan sınıflandırmada kızlarda doğum öncesi Mn seviyeleri ile sözel, nicel ve genel bilişsel ölçekler arasında pozitif ve faydalı bir ilişki olduğu gösterilmiştir ( $\beta$ (\%95GA): $4(0,03,7,96), 4,5(0,43,8,57)$ ve 4,32 (sırasıyla 0,6, 8,05). Çalışma sonuçlarının özellikle doğum öncesi dönemde diyetle ilgili sağlığı teşvik eden politikaların, Mn gibi mikro besin eksikliklerinin giderilmesinde yararlı olabileceği önerilmiştir [74].

Rahman ve ark. (2021) Bangladeş'in dokuz ilçesinde bulunan kuyulardan temin edilen içme suyundaki $\mathrm{Mn}$ düzeyini incelemişlerdir. Yüz-yetmiş (170) su numunesi toplanmış ve Mn miktarı atomik absorpsiyon spektroskopisi ile belirlenmiştir. Sirajganj, Meherpur, Chuadanga, Jhenaidah, Magura, Faridpur, Jashore, Satkhira ve Khulna kuyu suyu örneklerinde bulunan Mn seviyeleri 0,37-1,86,
0,10-4,11,0,30-0,76,0,26-0,94,0,01-0,18,0,21-1,78, 0,08-1,23, 0,05-0,27 ve 0,01-2,11 mg/L olarak bulunmuştur. Çalışmada, Mn seviyesinin sırasıyla Bangladeş İçme Suyu Standardı ve WHO önerisinin $0,1 \mathrm{mg} / \mathrm{L}$ ve 0,4 mg/L'nin üzerinde olduğu ortaya konulmuştur. Maksimum Mn kontamine seviyesi 4,11 mg/L'ye (ortalama 0,53 $\mathrm{mg} / \mathrm{L})$ ulaşmıştır [75].

\section{MANGANEZ TOKSİSİTESİ VE TEDAVİSİ}

Manganez etkileniminde ilk yapılması gereken uygulama, maruz kalan kişiyi kaynaktan uzaklaştırmaktır. Akut etkilenme sonucu pnömoni, bronşit gibi solunum sistemi patolojilerinin gelişimi söz konusu ise destek tedavi (oksijen, uygun pozisyon, vb.) verilmelidir. MMT'ye cilt yoluyla maruz kalım sonrası etkilenen alan bol su ve sabunla temizlenmelidir. MMT etkilenimi sonrası solunum sistemi semptomları gelişmişse kişi hastanede gözlem altında tutulmalıdır. Ayrıca, bireylerin böbrek ve karaciğer fonksiyon testleri yakından izlenmelidir.

Literatürde, Mn toksisitesine bağlı santral sinir sistemi bulguları gelişen olgularda, Mn'i santral sinir sisteminden uzaklaştırmayı ve bu yol ile klinik bulgularda düzelmeyi amaçlayan yaklaşımlar bulunmaktadır. İntravenöz etilendiamin-tetraasetik asit (EDTA) ile şelasyon uygulamasını takiben, kandaki Mn seviyelerinde azalma ve idrarda serbest Mn atılımı artmaktadır [63]. Herero Hernandez ve ark.'nın[77], Mn'den etkilenen yedi kaynakçıya 2 g kalsiyum-di-sodyum-etilen-di-amin-tetra-asetik asit ( $\mathrm{CaNa}_{2}$ EDTA) uyguladığı çalışmada, dört hastanın semptomlarında azalma ve bir hastanın titremesinde kısmen azalma olduğu rapor edilmiştir. Hastaların klinik durumlarındaki iyileşmeye, radyolojik iyileşmenin de eşlik ettiği bildirilmiştir. İlgili araştırma sonucunda, manganizmi olan bireylerde nöral hasar başlamadan önce erken dönemde başlatılan $\mathrm{CaNa}_{2} \mathrm{EDTA}$ başlanmasının önemli olabileceği 
öne sürülmüştür. Etkili tedavi seçeneklerinin yokluğunda ve levodopaya zayıf yanıtın varlığında, özellikle erken teşhis edilen ve hafif semptomlar gösteren manganizmi olan hastalarda şelasyon tedavisinin denenebileceği önerilmektedir [2]. Bununla birlikte, EDTA'nın, kan beyin bariyerinden zayıf penetrasyonu ve sudaki çözünürlüğünün yüksek olmasının Mn'in nörotoksik etkilerini iyileştirmedeki rolünün daha iyi araştırılması gerektiği vurgulanmaktadır.

Tedavi açısından değerlendirilen moleküllerden olan Para-amino-salisilik-asit (PAS) ve metaboliti, N-asetil-paraamino-salisilik asitin (Ac-PAS), hem Mn'i bağlayabildiği hem de vücutta depolanan Mn’i uzaklaştırabildiğine yönelik bulgulara ulaşılmıştır. PAS, tüberküloz tedavisinde klasik ilaçlara alternatif olarak kullanılan moleküllerden biridir. Kan beyin bariyeri penetrasyonu açısından, beyin dokusunda hem PAS hem de Ac-PAS tespit edilebildiği için manganizmi olan hastalarda bu iki ilacın da potansiyel bir şelasyon seçeneği olabileceği bildirilmiştir [19]. Yoon ve ark. [77], deneysel çalışmalarında PAS'ın insan nöroblastomunda Mn kaynaklı apoptozu bloke ettiğini göstermiştir. Jiang ve ark. [78], kronik Mn maruz kalımına bağlı gelişen sekonder parkinsonizm gelişen elli yaşındaki bir hastaya 4 ay boyunca 6 gr PAS içeren 15 kür uygulamıştır. Yedi aylık takipte, hastanın semptomlarının devam ettiği, ancak 17 yıllık takip ziyaretinde hafif bir el titremesi ve yürüme anormalliğinin bulunduğu, titreme, tetani ve şiddetli yürüyüş bozukluğu gibi durumların kaybolduğunu bildirmişlerdir.

\section{MANGANEZ MARUZ KALIMININ ÖNLENMESİ}

Kaynak dumanları ve metalurjik işlemler sırasında açığa çıkan aerosoller, Mn'e maruz kalmanın birincil kaynağıdır ve çoğu önleyici politika, bu toksik inhalasyonları azaltmayı amaçlamaktadır. Amerika Birleşik Devletleri Ulusal İş
Sağlığı ve Güveliği Enstitüsü (NIOSH), $1 \mathrm{mg} / \mathrm{m}^{3} \mathrm{Mn}$ TWA seviyelerini önermektedir [6]. Bu seviyenin çok altındaki konsantrasyonlara kronik maruz kalımdan sonra Mn ile ilişkili nörolojik toksisite gözlendiğinden, Amerikan Hükümet Endüstriyel Hijyenistler Konferansı (ACGIH), 2016 yılında bu sınırı 0,02 mg/m³'e düşürmüştür [79]. Bu gerekli üst sınır içinde seviyelerin korunmasını ve işçilerin mesleki maruz kalımının en aza indirilmesini sağlamak için sıkı politikalar oluşturulmuştur. Genel ortam havalandırması kapsamında hava değişimini sağlayan fanlar, toksik dumanların yoğun olarak açığa çıktığı iş istasyonlarındaki (örn. kaynak işi) çalışanların maruz kalımını engellemede yeterli olmamaktadır; dolayısıyla bu alanlarda lokal havalandırmanın sağlanması gereklidir. Operatörün maruz kalımının engellendiği bir sistemde çalışan robotik kaynak yöntemi, maskeler ve eldivenler dahil kişisel koruyucu ekipmanların kullanılması ve hava kalitesinin düzenli olarak ölçülmesi iş yerinde kural olmalıdır. İşçiler sağlık riskleri konusunda iyi eğitilmeli ve bilgilendirilmeli ve eve götürülen maruz kalımı önlemek için iş yerinden ayrılmadan önce tüm kıyafetleri çıkarmaları ve değiştirmeleri tavsiye edilmelidir. Erken koruyucu önlemleri başlatmak için hastalık belirtilerinin erken dönemde belirlenmesi amacıyla, işçiler koruyucu ekipmanın uygunluğu ve sağlık durumları açısından rutin olarak değerlendirilmelidir. İş sağlığı ve güvenliği açısından ilgili kurumlar, özel ve kamu iş yeri yöneticileri ve çalışanları, güvenli ve sağlıklı bir çalışma ortamı oluşturmak ve sağlık tehlikelerini en aza indirirken en yüksek verimliliği elde etmek için bir ekip olarak çalışmalıdır [80,81]. Çevresel maruz kalımlar açısından, musluk ve şişelenmiş su genellikle güvenlidir ve düşük $\mathrm{Mn}$ seviyeleri içerirken, sanayi sitelerine yakın yaşayan insanlar tüketim için kuyu suyunu kullanırken dikkatli olmalı ve yetkili kurumlarca belirlenen Mn seviyelerinin altında kalmasını sağlamak için su düzenli olarak analiz edilmelidir. 
Daha önce de değinildiği gibi, demir eksikliği, artan Mn emilimini destekler; bu nedenle çocuklar demir eksikliği ve anemi açısından izlenmeli ve bu durumlar saptanarak yönetilmelidir. İşlek bir karayolunun yakınında olduğu gibi yüksek trafik yoğunluğuna sahip alanlardan alınan hava örneklerinde, akaryakıtlardaki MMT kullanımı nedeniyle daha yüksek miktarlarda Mn bulunur. Bu alanlarda yaşayan bireyler, herhangi bir Mn zehirlenmesi belirtisi açısından izlenmelidir.

\section{SONUÇ VE ÖNERİLER}

Manganez endüstriyel işlemlerde yaygın olarak kullanıldığından, doğrudan veya dolaylı olarak Mn'in toksik etkilerine maruz kalan çalışanların sayısı oldukça fazladır. Nörologlar ve hareket bozukluğu uzmanları, dejeneratif nedenlerin yanı sıra parkinsonizmin toksik etiyolojilerini de dikkate almalıdır. İçme suyuna erişim kaynağı, deniz ürünleri tüketimi veya potansiyel bir metal toksisite kaynağının yakınında yaşama dahil olmak üzere ayrıntılı bir mesleki ve çevresel öykünün alınması önemlidir. Manganizm ve hipermanganizme bağlı ortaya çıan parkinsonizm hastalarının levodopaya olan yanıtı oldukça zayıftır ve bu olgularda şelasyon tedavisinin yararı konusunda bir uzlaşı bulunmamaktadır. Bu nedenle, diğer ağır metallerde olduğu gibi, Mn maruz kalımı ve sağlık etkilerinin yönetiminde tedaviden daha çok önlemeye odaklanılması, sağlık ve güvenlik önlemlerinin alınması, madencilik ve kaynakçllık sektörleri başta olmak üzere iş yerlerinde Mn'in bireysel ve çevresel etkilerini azaltmaya yönelik kural ve yasal düzenlemelerin sıkı uygulanması gerekmektedir.

Genel mühendislik önlemlerinden olan sslak işlemler (çalışma ortamının nemlendirilmesi), kapalı çalışma ortamının oluşturulması, lokal egzoz havalandırma gibi uygulamaların oluşturulması, genel havalandırma sistemlerinin kurulması, gerekli durumlarda çalışanlara uygun maskele- rin temin edilmesi ve kullandırılması, çalışma ortamında yeterli işaretleme yapılması konularına öncelik verilmelidir. İş yeri ortamını değerlendirme açısından iş yeri havasında Mn konsantrasyonu ölçülmelidir. Ayrıca, işe giriş ve periyodik muayenelerin de yapılmasına, maruz kalım riski olan çalışanların iş yeri eğitimlerinde işe ve maruz kalıma özgü eklemelere yer verilmesine özen gösterilmelidir.

YAzAR KatKIlari: Yazarların katkıları eşit düzeydedir.

ÇıKar ÇaTıŞMASI: Yazarlar herhangi bir çıkar çatışması olmadığını, makalede araşıırma ve yayın etiğine uyulduğunu beyan ederler.

Finansal Destek: Bu çalışmada herhangi bir kişi, kurum veya kuruluştan finansal destek alınmamıştır.

Eтік Коміте ONAYı: İnsan örneği veya deneysel çalısma içermediğinden etik kurulu oluru gerekmemiştir.

\section{KAYNAKÇA}

[1] ATSDR 2012. Toxicological Profile for Manganese, Agency for Toxic Substances and Disease Registry. US Public Health Service.

[2] Kazeem B, Salako Mahbub MU. (2014). Manganese. Ladou J, Harrison RJ. (Ed.). Occupational\&Envorimental Medicine (s.918-920). New York:Mc Graw Hill Education

[3] T.C. Çalışma ve Sosyal Güvenlik Bakanlığı. (2012). Meslek Hastalıkları ve İş ile İlgili Hastalıklar Tanı Rehberi. Ankara: T.C. Çalışma ve Sosyal Güvenlik Bakanlığı.

[4] WHO. Manganese and Its Compounds: Environmental Aspects. Geneva, 2004: 6-7.

[5] Singaraju M, Singaraju S, Parwani R., 2012. Cytogenetic biomonitoring in petrol station attendants: A micronucleus study. Journal of Cytology/Indian Academy of Cytologists, 29:1-5.

[6] Williams M, Todd GD, Roney N, Crawford J, Coles C, McClure PR, et al. Toxicological Profile for Manganese. Atlanta (GA): Agency for Toxic Substances and Disease Registry (US); 2012 Sep.

[7] Azcona-Cruz MI, Rothenberg SJ, Schnaas L, Zamaro -Munoz JS, Romeroplaceres M. Lead-Glazed Cera- 
mic Ware and Blood Lead Levels of Children in the City of Oaxaca, Mexico. Archives of Environmental Health. 2000:55(3):217-222.

[8] Carrington CD, Bolger PM. Toxic Metals; Lead. Encylopadia of Food Safety. 2014 (2):349.

[9] Agency for Toxic Substances and Disease Registry Toxicological Profile for Manganese. (2012). ATSDR. Erişim: 6 Mayıs 2021 http://www.atsdr. cdc.gov/toxprofiles/tp151.pdf.

[10] Zeidler-Erdely PC, Erdely A, Antonini JM. Immunotoxicology of arc welding fume: Worker and experimental animal studies. Journal of Immunotoxicology. 2012;9(4):411-25.

[11] Erdely A, Antonini JM, Young S-H, Kashon ML, Gu JK, Hulderman T, et al. Oxidative stress and reduced responsiveness of challenged circulating leukocytes following pulmonary instillation of metal-rich particulate matter in rats. Particle and Fibre Toxicology. 2014;11(1):34.

[12] Shoeb M, Kodali V, Farris B, LM, Meighan T, Salmen R, et al. Evaluation of the molecular mechanisms associated with cytotoxicity and inflammation after pulmonary exposure to different metal-rich welding particles. Nanotoxicology. 2017;11(6):725-36.

[13] Taube F. Manganese in occupational arc welding fumes: Aspects on physiochemical properties, with focus on solubility. Annals of Occupational Hygiene. 2012;57(1):6-25.

[14] Antonini JM, Roberts JR, Chapman RS, Soukup JM, Ghio AJ, Sriram K. Pulmonary toxicity and extrapulmonary tissue distribution of metals after repeated exposure to different welding fumes. Inhalation Toxicology. 2010;22(10):805-16.

[15] Chia SE, Foo SC, Gan SL, Jeyaratnam J, Tian CS. Neurobehavioral functions among workers exposed to manganese ore. Scand J Work Environ Health 1993;19:264-270.

[16] Lucchini R, Selis L, Folli D, Apostoli P, Mutti A, Vanoni $\mathrm{O}$, et al. Neurobehavioral effects of manganese in workers from a ferroalloy plant after temporary cessation of exposure. Scand J Work Environ Health 1995;21:143- 149.

[17] Myers JE, Thompson ML, Ramushu S, Young T, Jeebhay MF, London L, et al. The nervous system effects of occupational exposure on workers in a South African manganese smelter. Neurotoxicology 2003;24:885-894.

[18] Lee EY, Flynn MR, Lewis MM, Mailman RB, Huang $\mathrm{X}$. Welding-related brain and functional changes in welders with chronic and low-level exposure. Neurotoxicology 2018;64:50-59.

[19] O’Neal SL, Zheng W. Manganese toxicity upon over exposure: A decade in review. Curr Environ Health Rep 2015;2:315-328.

[20] Zayed J. Use of MMT in Canadian gasoline: health and environment issues. American Journal of Industrial Medicine 2001; 39(4), 426-433.

[21] Pouchieu C, Piel C, Carles C, Gruber A, Helmer C, Tual S, et al. Pesticide use in agriculture and Parkinson's disease in the AGRICAN cohort study. Int J Epidemiol 2018;47:299-310.

[22] Mergler D, Baldwin M, Bélanger S, Larribe F, Beuter A, Bowler R, et al. Manganese neurotoxicity, a continuum of dysfunction: Results from a community based study. Neurotoxicology 1999;20:327-342.

[23] Lucchini RG, Albini E, Benedetti L, Borghesi S, Coccaglio R, Malara EC, et al. High prevalence of parkinsonian disorders associated to manganese exposure in the vicinities of ferroalloy industries. American Journal of Industrial Medicine 2007;50: 788800.

[24] Standridge JS, Bhattacharya A, Succop P, Cox C, Haynes E. Effect of chronic low level manganese exposure on postural balance: A pilot study of residents in Southern Ohio. J Occup Environ Med 2008;50:1421-1429.

[25] Winder BS. Manganese in the air: Are children at greater risk than adults? J Toxicol Environ Health A 2010;73:156-158.

[26] Kullar SS, Shao K, Surette C, Foucher D, Mergler D, Cormier $\mathrm{P}$, et al. A benchmark concentration analysis for manganese in drinking water and IQ deficits in children. Environ Int 2019;130:104889.

[27] Neal AP, Guilarte TR. Mechanisms of lead and manganese neurotoxicity. 700. Toxicol Res (Camb) 2013;2:99-114.

[28] Abdalian R, Saqui O, Fernandes G, Allard JP. Effects of manganese froma commercial multi-trace element supplement in a population sample of Canadian patients on long-term parenteral nutrition. JPEN J Parenteral Nutr 2013;37:538-543.

[29] Koksal A, Baybas S, Sozmen V, Koksal NS, Altunkaynak Y, Dirican A, et al. Chronic manganese toxicity due to substance abuse in Turkish patients. Neurol India 2012;60:224-227.

[30] Smith D., Woodall GM., Jarabek AM, \& Boyes WK. Manganese testing under a clean air act test rule and the application of resultant data in risk assessments. 
Neurotoxicology 2018; 64, 177-184.

[31] Hasan H. Understanding the Element of the Periodic Table: Manganese. New York, Rosen Central, 2008:4 -12 .

[32] Çelik A, Abalı Y, Edgünlü G, Uzunoğlu S, \& Tirtom VN. İnsan saçında bulunan (Manisa ilinin üç farklı yerleşim bölgesinde) bazı ağır metallerin ICP-OES yöntemi ile tayini. Ekoloji 2009; 19(73), 71-75.

[33] Goldhaber SB. Trace element risk assessment: essentiality vs. toxicity.Regul Toxicol Pharmacol 2003; 38 (2):232-42.

[34] Cikrt M. VEGJ. Manganese. Environmental Health Criteria: Genevra; 1981. Report No.: 17.

[35] Lucchini R, Placidi D, Cagna G, Fedrighi C, Oppini M, Peli $M$, et al. Manganese and Developmental Neurotoxicity. Neurotoxicity of Metals: U.S.A., Springer; 2017.13-34.

[36] Nordberg G., Fowler BA, Nordberg M, Friberg LT. Handbook on The Toxicology of Metals, U.S.A.: Academic Press; 2014.

[37] OSHA Occupational Safety\&Health Administration Manganese Fume, Manganese Compounds. [Internet]. [Erişim tarihi: 01.05.2021] Erişim adresi: https://www.osha.gov/dts/chemical

[38] Raval G, Straughen JE, McMillin GA, Bornhorst JA.Unex- plained hemolytic anemia with multiorgan failure. Clin Chem 2011; 57(1485).

[39] Roels H, Djubgang J, Buchet JP, Bernard A, \& Lauwerys R. Evolution of cadmium-induced renal dysfunction in workers removed from exposures. Scandinavian Journal of Work, Environment \& Health 1982; 191-200.

[40] Agency for Toxic Substances and Disease Registry, Division of Toxicology, 2012. Toxicolgical Profile for manganese. Update Draft for Public Comments. ATSDR, Atlanta GA.

[41] Pfeifer GD, Roper, J.M., Dorman, D., Lynam, D.R., 2004. Health and environmental testing of manganese exhaust products from use of methylcyclopentadienyl manganese tricarbonyl in gasoline. Sci Total Environ., 334- 335:397-408.

[42] Goyer RA. and Clarkson TW. Toxic Effects of Metals. Casarett and Doullis Toxicology. New York: McGraw-Hill; 2001.

[43] Nogawa K, Kobayashi E, Okubo Y, Suwazono Y. Environmental cadmium exposure, adverse effects and preventive measures in Japan. Biometals 2004;17 (581).
[44] Kulshreshtha D., Ganguly J, \& Jog M. Manganese and Movement Disorders: A Review. Journal of Movement Disorders 2021;14(2), 93.

[45] Aschner M, Erikson KM, Hernández EH, \& Tjalkens R. Manganese and its role in Parkinson's disease: From transport to neuropathology. Neuromolecular Medicine 2009;11(4), 252-266.

[46] Chen P, Chakraborty S, Mukhopadhyay S, Lee E, Paoliello MM, BowmanAB, et al. Manganese homeostasis in the nervous system. J Neurochem 2015;134:601-610.

[47] Huang C. Parkinsonism induced by chronic manganese intoxication-an experience in Taiwan. Chang Gung Medical Journal 2007;30(5), 385.

[48] Harischandra DS, Ghaisas S, Zenitsky G, Jin H, Kanthasamy A, Anantharam V, \& Kanthasamy AG. Manganese-induced neurotoxicity: New insights into the triad of protein misfolding, mitochondrial impairment, and neuroinflammation. Frontiers in Neuroscience, 2019;13, 654.

[49] Gavin CE, Gunter KK, Gunter TE. Manganese and calcium efflux kinetics in brain mitochondria. Relevance to manganese toxicity. Biochem J 1990; 266:329-334.

[50] Kowaltowski AJ, Castilho RF, \& Vercesi AE. Ca (2+) -induced mitochondrial membrane permeabilization: role of coenzyme Q redox state. American Journal of Physiology-Cell Physiology 1995;269(1), 141-147.

[51] Gonzalez-Cuyar LF, Nelson G, Criswell SR, Ho P, Lonzanida JA, Checko- way H, et al. Quantitative neuropathology associated with chronic manganese exposure in South African mine workers. Neurotoxicology 2014; 45:260-266.

[52] Harischandra DS, Rokad D, Neal ML., Ghaisas S., Manne S, Sarkar S, \& Kanthasamy AG. Manganese promotes the aggregation and prion-like cell-to-cell exosomal transmission of $\alpha$-synuclein. Science Signaling, 2019;12(572).

[53] Calne DB, Chu NS, Huang CC, Lu CS, Olanow W. Manganism and idiopathic parkinsonism: Similarities and differences. Neurology 1994;44;1583- 1586.

[54] Ikeda K, Ebina J, Kawabe K, Iwasaki Y. Dopamine transporter imaging in Parkinson disease: Progressive changes and therapeutic modification after antiparkinsonian medications. Intern Med 2019;58:1665 -1672 .

[55] Andruska KM, Racette BA. Neuromythology of manganism. Curr Epidemiol Rep 2015;2:143-148.

[56] Josephs KA, Ahlskog JE, Klos KJ, Kumar N, Fealey 
RD, Trenerry MR, et al. Neurologic manifestations in welders with pallidal MRI T1 hyperintensity. Neurology 2005;64:2033-2039.

[57] Huang CC, Chu NS, Lu CS, Chen RS, Calne DB. Long-term progression in chronic manganism: Ten years of follow-up. Neurology 1998;50:698-700.

[58] Rocha E, Vale TC., Kok F, Pedroso JL., \& Barsottini, OG. Teaching Video NeuroImages: Spinocerebellar ataxia type 3 presenting with a cock-walk gait phenotype. Neurology 2017;89:e192.

[59] Fasano A, Bloem BR. Gait disorders. Continuum (MinneapMinn) 2013; 19:1344-1382.

[60] Ghosh R, Dubey S, Chatterjee S, Ghosh M, Ray BK, Benito-León J. Hypermanganesemia induced chorea and cognitive decline in a tea seller. Tremor Other Hyperkinet Mov (N Y) 2020;10:45.

[61] Ono K, Komai K, Yamada M. Myoclonic involuntary movement associated with chronic manganese poisoning. J Neurol Sci 2002;199:93-96.

[62] Liu J, Jin L, Zhang L, Li Z, Wang L, Ye R, \& Ren A. Placental concentrations of manganese and the risk of fetal neural tube defects. Journal of Trace Elements in Medicine and Biology 2013; 27(4), 322-325.

[63] Avila DS, Puntel RL, Aschner M. Manganese in health and disease. MetIons Life Sci 2013;13:199-227.

[64] Andersen O. Principles and recent developments in chelation treatment of metal intoxication. Chem Rev 1999;99:2683-2710.

[65] Eastman RR, Jursa TP, Benedetti C, Lucchini RG, Smith DR. Hair as a biomarker of environmental manganese exposure. Environ. Sci. Technol 2013; 47 (3),1629-1637.

[66] Jarvisalo J, Olkinuora M, Kiilunen M, Kivisto $H$, Ristola P, Tossavainen A., et al. Urinary and blood manganese in occupationally nonexposed populations and in manual metal arc welders of mild steel. Int. Arch. Occup. Environ. Health 1992; 63(7), 495501.

[67] Michalke B, and Fernsebner K. New insights into manganese toxicity and speciation. J. Trace Elem. Med. Biol 2014;28(2), 106-116.

[68] Özdek U, Alacabey İ, Alacabey NA.,Kömüroğlu AU, Kul AR, Atasoy N, Üçler R. Petrol İstasyonu Çalışanlarında Manganez (Mn) Düzeyinin Belirlenmesi. Yüzüncü Y1l Üniversitesi Fen Bilimleri Enstitüsü Dergisi 2017;22(2), 97-101.

[69] Kendzia B, Van Gelder R, Schwank T, Hagemann C, Zschiesche W, Behrens T, \& Pesch B. Occupational exposure to inhalable manganese at German workplaces. Annals of Work Exposures and Health 2017;61 (9), 1108-1117.

[70] Yang H, Wang J, Yang X, Wu F, Qi Z, Xu B., \& Deng Y. Occupational manganese exposure, reproductive hormones, and semen quality in male workers: A cross-sectional study. Toxicology and Industrial Health 2019; 35(1), 53-62.

[71] Palzes VA, Sagiv SK, Baker JM, Rojas-Valverde D, Gutiérrez-Vargas R, Winkler MS, \& Mora AM. Manganese exposure and working memory-related brain activity in small holder farm workers in Costa Rica: Results from a pilot study. Environmental Research 2019; 173, 539-548.

[72] Chen X, Liu Z, Ge X, Luo X, Huang S, Zhou Y, \& Yang X. Associations between manganese exposure and multiple immunological parameters in manganese-exposed workers healthy cohort. Journal of Trace Elements in Medicine and Biology 2020; 59, 126454.

[73] Dlamini WW, Nelson G, Nielsen SS, \& Racette BA. Manganese exposure, parkinsonian signs, and quality of life in South African mine workers. American Journal of Industrial Medicine 2020; 63(1), 36-43.

[74] Irizar A, Molinuevo A, Andiarena A, Jimeno-Romero A, San Román A, Broberg K, \& Lertxundi A. Prenatal manganese serum levels and neurodevelopment at 4 years of age. Environmental Research 2021; 197, 111172.

[75] Rahman MA, Hashem MA., Rana MS, \& Islam MR. Manganese in potable water of nine districts, Bangladesh: human health risk. Environmental Science and Pollution Research 2021;1-13.

[76] Herrero Hernandez E, Discalzi G, Valentini C, Venturi F, Chiò A, Carmellino $\mathrm{C}$, et al. Follow-up of patients affected by manganese-induced parkinsonism after treatment with CaNa2EDTA. Neurotoxicology 2006; 27:333-339.

[77] Yoon H, Kim DS, Lee GH, Kim JY, Kim DH, Kim $\mathrm{KW}$, et al. Protective effects of sodium para-amino salicylate on manganese-induced neuronal death: The involvement of reactive oxygen species. J Pharm Pharmacol 2009; 61:1563-1569.

[78] Jiang YM, Mo XA, Du FQ, Fu X, Zhu XY, Gao HY, et al. Effective treatment of manganese-induced occupational parkinsonism with p-aminosalicylic acid: A case of 17-year follow-up study. J Occup Environ Med 2006;48:644-649.

[79] Racette BA, Searles Nielsen S, Criswell SR, Sheppard 
L, Seixas N, Warden MN, et al. Dose-dependent progression of parkinsonism in manganese-exposed welders. Neurology 2017;88:344-351.

[80] Canadian Centre for Occupational Health and Safety (CCOHS). Welding-fumes and gases [Internet]. Hamilton: Canadian Centre for Occupational Health and Safety; 2016. Available at: https://www.ccohs.ca/ oshan-swers/safety_haz/welding/fumes.html.

[81] Government of Canada. Canada Occupational Health and Safety Regu- lations (SOR/86-304) [Internet]. Ottawa: Department of Justice of Canada; 2018. Available at: https://laws.justice.gc.ca/eng/ regulations/sor-86- 304/index.html. 